\title{
KINERJA REKSA DANA SAHAM DENGAN MENGGUNAKAN METODE SHARPE, TRENYOR DAN JENSEN PADA PERIODE JANUARI 2014 SAMPAI DESEMBER 2015
}

\author{
Methirana \\ Program Studi Magister Manajemen Universitas Tarumanagara \\ shinmei288@gmail.com \\ Indra Widjaja \\ Program Studi Magister Manajemen Universitas Tarumanagara
}

\begin{abstract}
The purpose of the research is to analyze the types of equity funds in the stock market and analyze the performance of the funds equity method using sharpe, trenyor methods, and methods of jensen. The research method used is the method of data collection and processing of data by calculation in accordance with methods of sharpe, treynor method and methods of jensen. Method of data collection is composed of effective data from the website of the stock exchange. Calculation method consists of a method of sharpe, treynor method, and methods of jensen. The benefits of this comparison can give you an idea about the objective performance of mutual funds in Indonesia as one of the considerations for investors and potential investors in choosing the best mutual fund, and to an investment manager with the research expected to provide knowledge about the Investment Manager on the performance that they do. In addition to knowing the competition industry mutual funds in Indonesia so as to provide a reference for an investment manager as a determinant of investment policy to increase the return on investment and minimize risk. As well as for the community Provide knowledge and information on the performance of mutual funds in Indonesia.
\end{abstract}

Keywords : Sharpe, Treynor, Jensen, Mutual Fund.

Tujuan penelitian ialah untuk menganalisis jenis-jenis reksa dana di bursa saham, dan menganalisis kinerja reksa dana dengan menggunakan metode sharpe, metode trenyor, dan metode jensen. Metode penelitian yang digunakan adalah Metode Pengumpulan data dan pengolahan data dengan perhitungan sesuai dengan metode sharpe, metode treynor dan metode jensen. Metode Pengumpulan data dari data efektif di website bursa efek. Metode Perbandingan terdiri dari metode sharpe, metode treynor, dan metode jensen. Manfaat dari perbandigan ini dapat memberikan gambaran obyektif tentang kinerja reksa dana di Indonesia sebagai salah satu pertimbangan bagi investor dan calon investor dalam memilih reksa dana terbaik, dan untuk manajer investasi penelitian ini diharapkan dapat memberikan pengetahuan tentang manajer investasi pada kinerja perhitungan yang mereka lakukan. Selain dapat mengetahui persaingan industri reksa dana di Indonesia, juga dapat memberikan referensi bagi Manajer Investasi sebagai penentu kebijakan investasi untuk meningkatkan laba dan meminimalkan risiko investasi. Serta untuk Masyarakat Memberikan pengetahuan dan informasi tentang kinerja reksa dana di Indonesia. 


\section{PENDAHULUAN}

Menurut Pratomo dan Nugraha, (2009:6) Sedikitnya terdapat tiga alasan umum yang melatarbelakangi seseorang melakukan investasi, yaitu: pertama, adanya kebutuhan masa depan atau kebutuhan saat ini yang kurang mampu untuk dipenuhi saat ini; kedua, adanya keinginan seseorang untuk menambah atau melindungi nilai aset yang dimiliki; dan ketiga adalah adanya inflasi .

Menurut data BAPEPAM-LK untuk tahun 2016. komposisi Reksa Dana yang paling besar dipegang oleh Reksa Dana Saham yakni sebesar 38,46\% dan yang terendah adalah Reksa Dana Syariah Pasar Uang sebesar 0,34\%. Menurut Adler Manurung (2008) Reksa Dana Saham di Indonesia tidak sebesar Reksa Dana lainnya. Berdasarkan data Bapepam pada akhir Mei 2007 total aset Reksa Dana Saham sebesar Rp 5,02 triliun dan sudah terkalahkan oleh Reksa Dana Terproteksi. Hal itu membuktikan bahwa Reksa Dana Saham berkembang dengan sangat pesat.

Untuk melihat sampai sejauh mana kinerja Reksa Dana yang dimiliki, biasanya para Manajer Investasi melakukan evaluasi kinerja portofolio dengan berbagai metode. Hal itu dilakukan untuk mengetahui bagaimana kinerja portofolio. Oleh karena itu, diperlukan pengetahuan untuk mengukur investasi yang dipilih dapat memberikan return sebanding dengan tingkat risiko yang diterima. karena hal itu penulis melakukan penelitian yang berjudul "Menganalisis kinerja Reksa Dana Saham Dengan Menggunakan Metode Sharpe, Trenyor dan Jensen pada Perode Januari 2014 Sampai Desember 2015".

Dengan tujuan untuk mengetahui tentang produk-produk reksa dana saham, mengetahui kinerja Reksa Dana saham berdasarkan metode Sharpe, Treynor, dan Jensen, periode 2014-2015, dan mengetahui jenis reksa dana mana yang layak untuk investor dapat menginvestasikan dananya. Dan memberikan manfaat Bagi Investor dan Calon Investor dapat memberikan gambaran objektif tentang kinerja Reksa Dana saham di Indonesia sebagai salah satu pertimbangan bagi investor dan calon investor dalam memilih Reksa Dana dengan kinerja terbaik. Bagi Manajer Investasi dapat memberi gambaran bagi Manajer Investasi mengenai kinerja yang mereka lakukan. Selain itu untuk mengetahui persaingan industri Reksa Dana saham di Indonesia sehingga dapat memberikan referensi bagi Manajer Investasi sebagai penentuan kebijakan investasi guna meningkatkan keuntungan dan memperkecil risiko investasi yang dilakukannya. Dan bagi Masyarakat dapat memberikan pengetahuan dan meningkatkan informasi tentang kinerja Reksa Dana saham di Indonesia.

\section{TINJAUAN TEORI}

Menurut Tandelilin (2010) investasi adalah komitmen atas sejumlah dana atau sumber daya lainnya yang dilakukan pada saat ini dengan tujuan memperoleh sejumlah keuntungan di masa datang. Istilah investasi dapat berkaitan dengan berbagai macam aktivitas. Menginvestasikan sejumlah dana pada aset riil (tanah, emas, mesin atau bangunan), maupun aset finansial (deposito, saham ataupun obligasi) merupakan aktivitas investasi yang umumnya dilakukan. Adapun beberapa alasan mengapa seseorang melakukan investasi, yaitu:

\section{a. Untuk mendapatkan kehidupan yang lebih layak di masa datang}

Seseorang yang bijaksana akan berpikir bagaimana meningkatkan taraf hidupnya dari waktu ke waktu atau setidaknya berusaha bagaimana mempertahankan tingkat pendapatannya yang sekarang agar tidak berkurang di masa yang akan datang.

\section{b. Mengurangi tekanan inflasi}


Seseorang dapat menghindarkan diri dari risiko penurunan nilai kekayaan atau hak miliknya akibat adanya pengaruh inflasi dengan melakukan investasi dalam pemilikan perusahaan atau objek lain.

\section{c. Dorongan untuk hemat pajak}

Beberapa negara di dunia banyak melakukan kebijakan yang bersifat mendorong tumbuhnya investasi di masyarakat melalui pemberian fasilitas perpajakan kepada masyarakat yang melakukan investasi pada bidang-bidang usaha tertentu.

Menurut Asril Sitompul,. SH.LL.M (2000, 3-4), dalam bukunya ada beberapa pengertian Reksa Dana antara lain :

Menurut Undang-Undang No 8 Tahun 1995 tentang Pasar Modal mendefinisikan Reksa Dana sebagai berikut :

"Reksa Dana adalah wadah yang dipergunakan untuk menghimpun dana dari masyarakat pemodal untuk selanjutnya di investasikan dalam portofolio efek oleh Manajer Investasi”

Menurut Walter Updegrave dalam bukunya "Investing In Mutual Fund" adalah sebagai berikut :

"A mutual fund is essentially a company that pool money from investor like you and hires an investment adviser (usually know as the portofolio manager or fund manager to buy stock, bonds, money-market instrument, or a combination of all three of these securities with that pool of money. When you invest in a fund, you purchase shares that represent part ownership of the securities in the fund. These shares also entitle you to a share of the income and profits (or, yes, it happens, losses) that those securities generate"

Reksa Dana adalah suatu perusahaan yang menghimpun uang dari pemodal seperti anda dan memperkerjakan seorang manajer investasi (biasanya disebut manajer portofolio atau manajer Reksa Dana) untuk membeli saham, obligasi, surat-surat berharga, atau gabungan dari efek-efek tersebut dengan uang yang terkumpul itu. Apabila anda melakukan investasi di dalam Reksa Dana, anda membeli saham yang mewakili sebagian dari kepemilikan efek dalam Reksa Dana tersebut. Dengan demikian, anda berhak atas bagian dari penghasilan dan keuntungan (atau kerugian) yang dihasilkan oleh efek tersebut.

Menurut Amy L. Domini dan Peter D. Kinder dalam bukunya "Ethical Investing" adalah sebagai berikut :

"A mutual fund pools its shareholders' resources under professional management for specific purpose. The fund mnagers define the purpose when they start the fund and describe it in the fund's prospectus. The purpose may be nebulous, like providing high income. Or it may be as specific as investing in companies returning from the brink of bankruptcy or in particular goverment securities". 


\section{Metode Pengukuran Kinerja Reksa Dana Saham}

Kinerja Reksa Dana merupakan hasil yang diperoleh dari suatu Reksa Dana sehingga dapat diketahui perkembangannya. Hasil tersebut tentunya sangat penting untuk evaluasi kinerja serta pengambilan keputusan investasi untuk masa mendatang. Suatu Reksa Dana dapat dikatakan memiliki kinerja baik jika berada di atas Indeks Harga Saham Gabungan (IHSG) yang digunakan sebagai benchmark untuk menyimpulkan kinerja suatu Reksa Dana tersebut. Menurut Pratomo (2009), ada tiga metode pengukuran Reksa Dana dengan memasukkan unsur risiko ke dalamnya, yaitu:

a. Metode Sharpe merupakan jenis metode yang melibatkan Premium Risk sebagai perbedaan antara rata-rata kinerja yang dihasilkan oleh Reksa Dana dengan rata-rata kinerja investasi yang bebas risiko (risk free rate). Metode Sharpe dirumuskan dengan persamaan sebagai berikut: (Tandelilin, 2010).:

Dimana :

$$
\frac{\mathrm{SRD}=\mathrm{Rp}-\mathrm{Rf}}{\sigma \mathrm{p}}
$$

$\mathrm{S}_{\mathrm{RD}}$ : Nilai Sharpe Ratio

Dimana :

$$
\mathrm{Rp} \quad \text { : Rata - rata Return Reksa Dana }
$$

$\mathrm{S}_{\mathrm{RD}}$ : Nilai Sharpe Ratio

Rp : Rata - rata Return Reksa Dana

Rf : Rata - Rata Return investasi bebas resiko

$\sigma p \quad$ : Standart deviasi

Dari persamaan di atas dapat disimpulkan bahwa semakin tinggi indeks sharpe dibandingkan portofolio yang lain, semakin baik kinerja Reksa Dana tersebut (Tandelilin, 2010).

b. Metode Treynor merupakan ukuran kinerja portofolio yang dikembangkan oleh Jack Treynor. Sama halnya seperti metode Sharpe, pada metode Treynor kinerja portofolio dilihat dengan cara menghubungkan tingkat return portofolio dengan besarnya risiko dari portofolio tersebut. Perbedaannya dengan metode Sharpe adalah menggunakan garis pasar sekuritas (security market line) sebagai patok duga, dan bukan garis pasar modal seperti metode Sharpe. Garis pasar sekuritas (security market line) adalah garis yang menghubungkan tingkat return harapan dari suatu sekuritas dengan risiko sistematis (beta). security market line digunakan untuk menilai sekuritas secara individual pada kondisi pasar yang seimbang, yaitu menilai tingkat return yang diharapkan dari suatu sekuritas individual pada suatu tingkat risiko sistematis tertentu (beta). Asumsi yang digunakan oleh Treynor adalah bahwa portofolio sudah terdiversifikasi dengan baik sehingga risiko yang dianggap relevan adalah risiko sistematis (diukur dengan beta). Cara mengukur metode Treynor pada dasarnya sama dengan cara menghitung metode Sharpe, hanya saja risiko yang diukur dengan standar deviasi pada metode Sharpe diganti dengan beta portofolio. Metode Treynor suatu portofolio dalam periode tertentu dapat dihitung dengan menggunakan persamaan seperti berikut ini :

$$
\frac{\mathrm{TRD}=\mathrm{Rp}-\mathrm{Rf}}{\beta \mathrm{p}}
$$


Dimana :

$\mathrm{T}_{\mathrm{RD}}$ : Nilai Treynor Ratio

Rp : Rata - rata Return Reksa Dana

Rf : Rata - Rata Return investasi bebas resiko

$\beta \mathrm{p} \quad$ : Beta persamaan garis regresi linear berganda

Treynor berargumentasi bahwa portofolio yang dibentuk mengabaikan risiko unik dan meninggalkan risiko sistematik yang dapat diukur dengan Beta.

c. Metode Jensen juga melibatkan faktor beta ( ) di dalam perhitungannya yang didasarkan atas perkembangan Capital Asset Pricing Model (CAPM). Model ini menilai kinerja manajer investasi dalam menghasilkan nilai positif alfa (alpha). Semakin tinggi nilainya, semakin baik kinerja dari Reksa Dana tersebut. Metode Jensen dapat diukur dengan persamaan sebagai berikut: (Tandelilin, 2010).

Dimana :

$$
J R D=R p-[R f \dot{+}(R m-R f) \beta p]
$$

$$
\begin{aligned}
& \mathrm{J}_{\mathrm{RD}}: \text { Nilai Treynor Ratio } \\
& \mathrm{Rp}: \text { Rata - rata Return Reksa Dana } \\
& \mathrm{Rf}: \text { Rata - Rata Return investasi bebas resiko } \\
& \mathrm{Rm}: \text { rata-rata return benchmark (IHSG dan LQ45) } \\
& \beta \mathrm{p}: \text { Beta persamaan garis regresi linear berganda }
\end{aligned}
$$

Persamaan metode Jensen dengan metode Treynor adalah kedua metode ukuran kinerja portofolio tersebut menggunakan garis pasar sekuritas sebagai dasar untuk membuat persamaan. Sedangkan perbedaannya adalah bahwa metode Treynor sama dengan slope garis yang menghubungkan posisi portofolio dengan return bebas risiko, sedangkan metode Jensen merupakan selisih antara return portofolio dengan return portofolio yang tidak dikelola dengan cara khusus.

\section{Analisa Dan Pembahasan \\ Analisa data}

Pada penelitian ini reksa dana yang akan dianalisa adalah 20 Reksa Dana Saham. Analisis kinerja reksa dana dilakukan dengan menggunakan metode Sharpe, Trenyor dan Jensen. Data- data yang di perlukan dalam penelitian ini meliputi yaitu ; Suku Bunga Sertifikat Bank Indonesia, Indeks Pasar(rata-rata IHSG), dan Nilai Aktiva Bersih Reksa Dana. SBI yang mewakili tingkat pengembalian bebas resiko, serta IHSG yang mewakili tingkat pengembalian pasar digunakan sebagai benchmark bagi Reksa Dana Saham. 


\section{Pembahasan}

Rerata tingkat pengembalian dan standart deviasi reksa dana saham sesuai index pasar

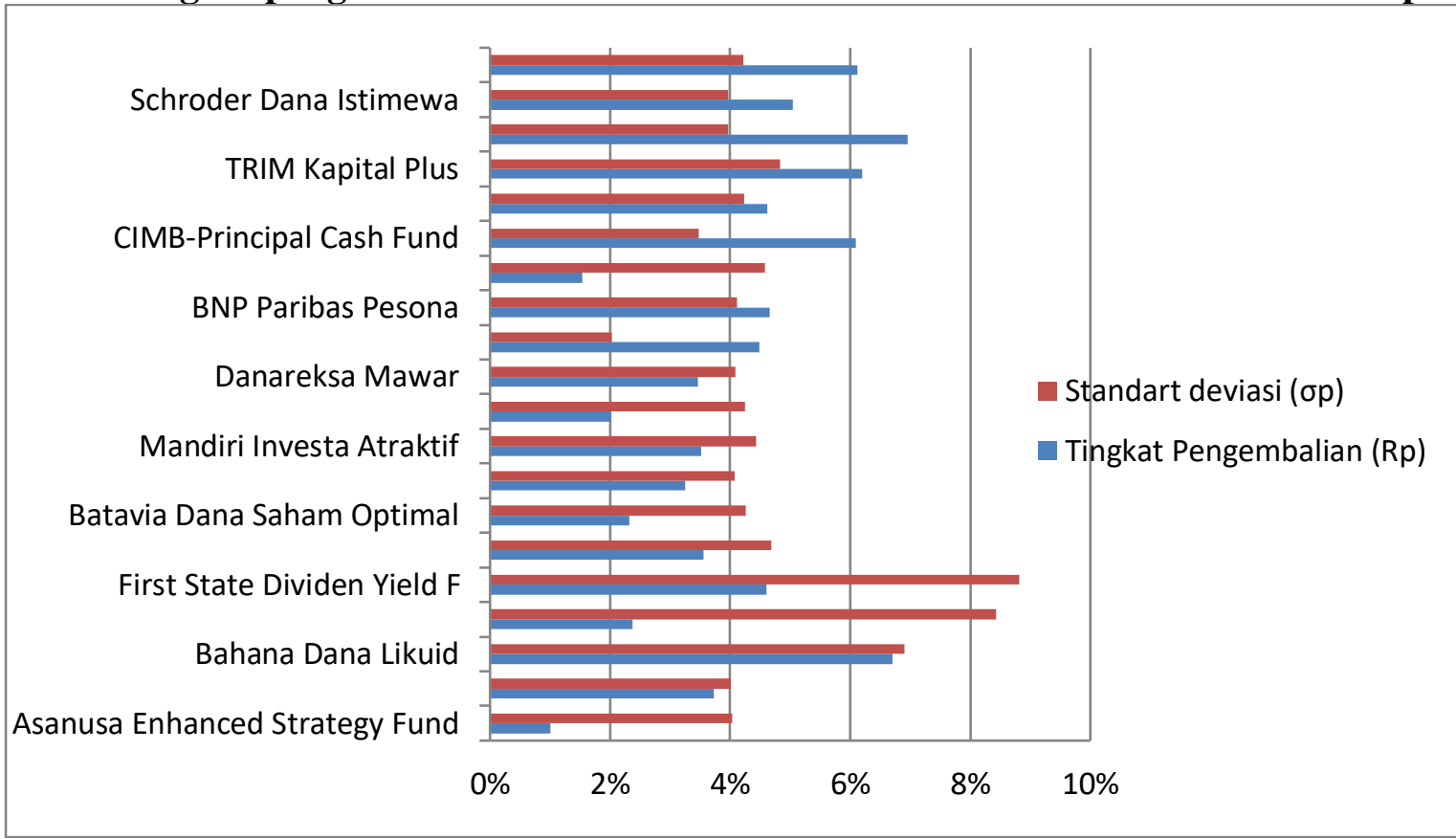

Dengan nilai rerata indeks pasar sebesar $0.234 \%$ maka berdasarkan grafik diatas dapat dilihat bahwa ada 10 dari 20 reksa dana saham yang memiliki rerata tingkat pengembalian yang lebih tinggi daripada indeks pasar, dan rerata tingkat pengembalian tertinggi dari 20 reksa dana saham menunjukkan kepada investor bahwa reksa dana tersebut dapat mendapatkan keuntungan

Untuk itu diperlukan analisis lebih lanjut dengan menggunakan metode sharpe, treynor, dan jensen yang akan memberikan hasil yang lebih baik bagi investor. Penggunaan ketiga metode ini akan memperhitungkan faktor resiko yang timbul dari setiap reksa dana.

\section{Pengukuran Kinerja reksa dana saham dengan metode Sharpe}

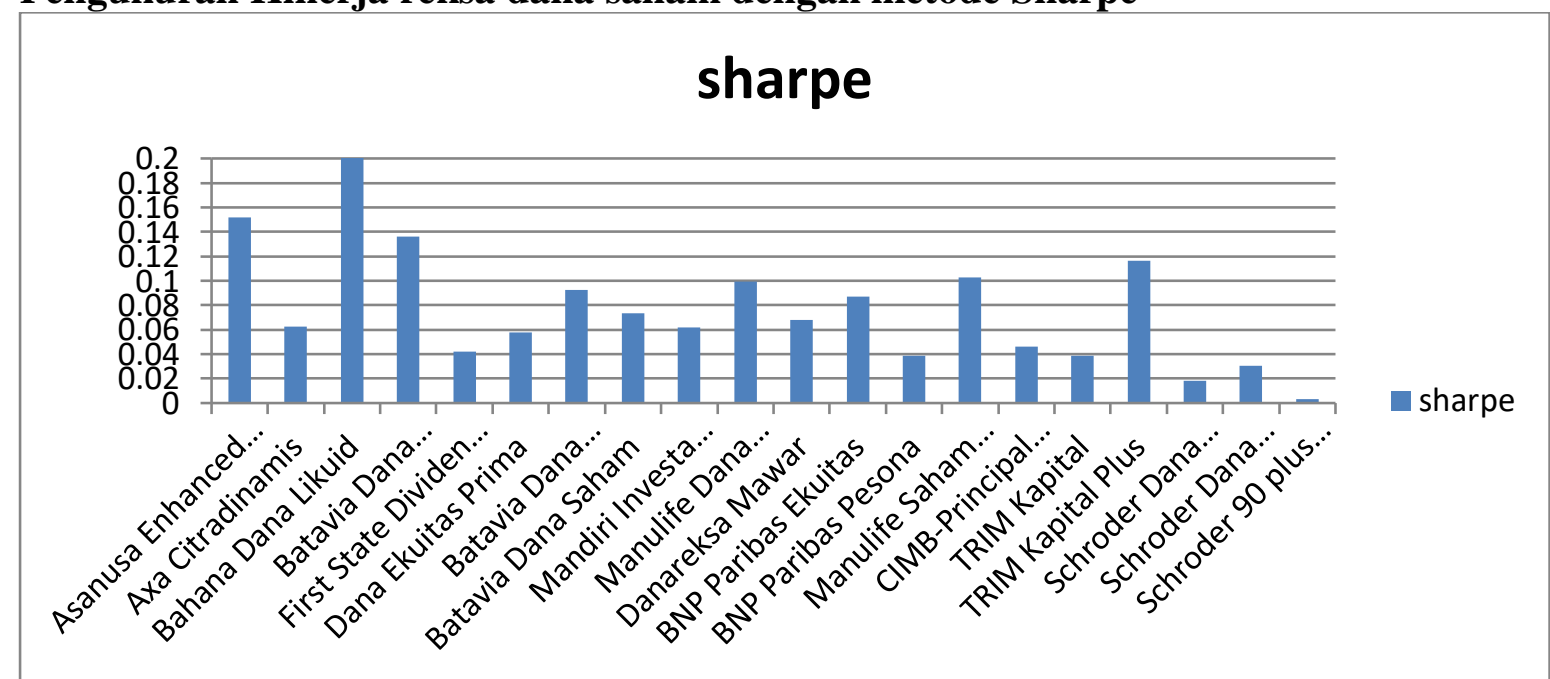

Sumber hasil metode Sharpe

Pada grafik ditampilkan data hasil perbandingan antara nilai rasio sharpe 20 produk reksa dana saham dan nilai rasio sharpe tingkat pengembalian indeks pasar (IHSG). Terdapat 6(enam) reksa dana yang berstatus overperformed, dengan nilai rasio sharpe yang melebihi 0,0920. 6(enam) reksa dana saham yang termasuk dalam kategori overperformed ialah : 
1) Asanusa Enhanced Strategy Fund

2) Batavia Dana Dinamis

3) Bahana Dana Likuid

4) Manulife Dana Saham

5) Manulife Saham Andalan

6) TRIM Kapital Plus

\section{Pengukuran Kinerja reksa dana saham dengan metode Treynor}

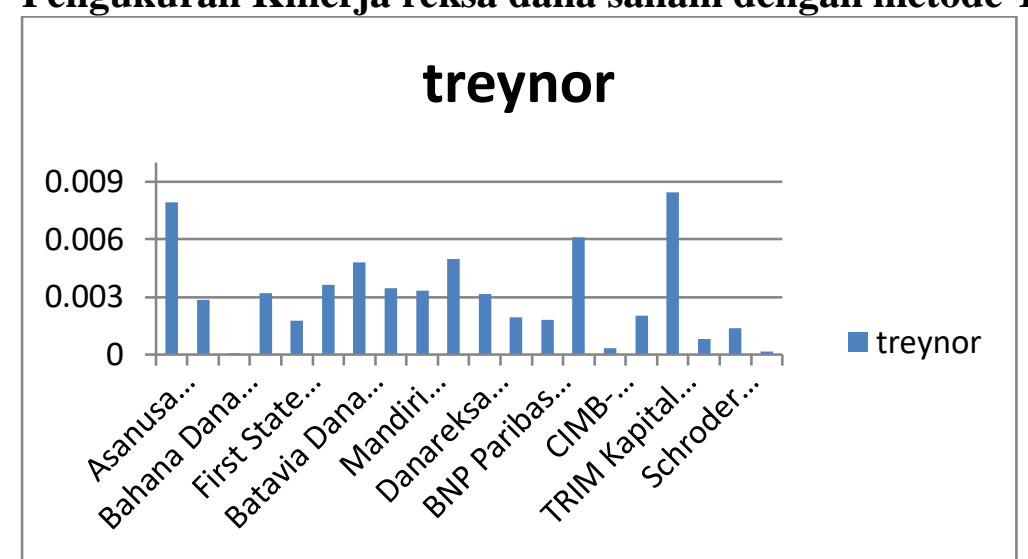

Sumber : hasil metode treynor

Hasil perbandingan nilai rasio treynor antara 20 reksa dana saham dan tingkat pengembalian indeks pasar menunjukan bahwa ada 5(lima) reksa dana saham yang memiliki kinerja overperformed. Ke 5 (lima) reksa dana tersebut adalah :

1) Asanusa Enhanced Strategy Fund

2) Batavia Dana Saham Optimal

3) Manulife Dana Saham

4) Manulife Saham Andalan

5) TRIM Kapital Plus

\section{Pengukuran Kinerja reksa dana saham dengan metode Jensen}

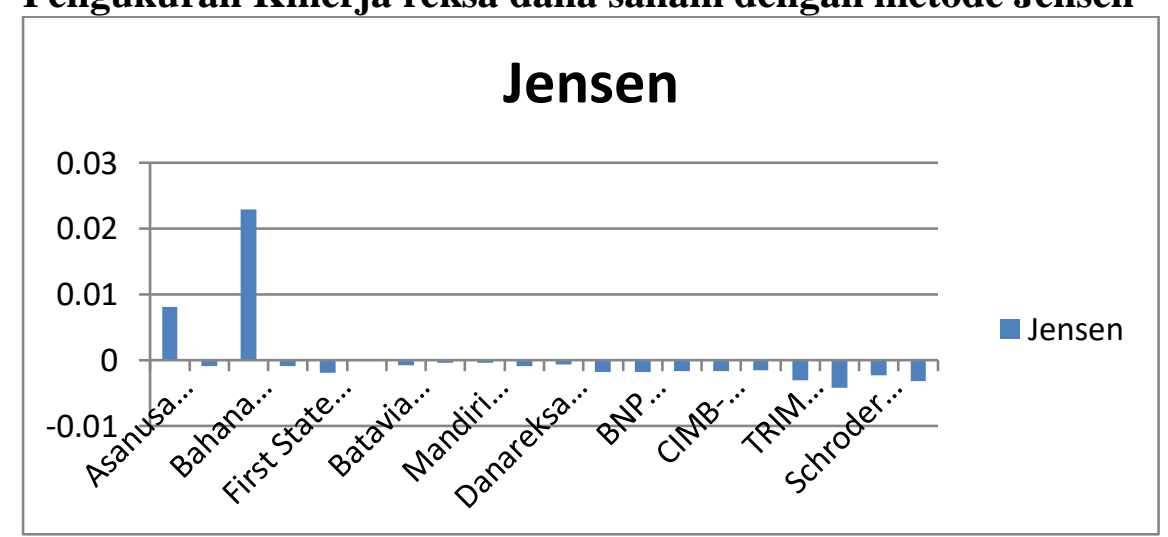

Sumber : hasil metode jensen

Berdasarkan nilai alpha dari 20 reksa dana saham pada gambar 4.5 maka hasil perbandingan nilai rasio jensen dan tingkat pengembalian indeks pasar menunjukan bahwa ada 5(lima) reksa dana saham yang memiliki kinerja overperformed. Ada 2 (dua) reksa dana tersebut adalah Asanusa Enhanced Strategy Fund dan Bahana Dana Likuid.

\section{Perbandingan Nilai Reksa dana saham dengan tiga metode}




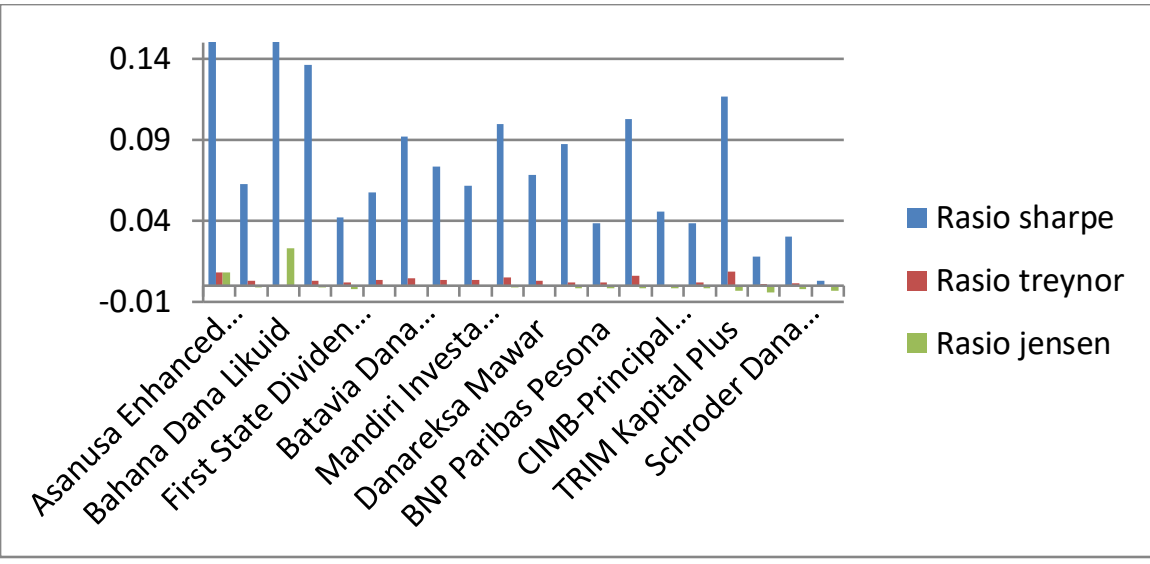

Berdasarkan hasil perbandingan pada gambar dapat dilihat hasil perhitungan dengan pengukuran ketiga metode dalam analisa reksa dana saham yang akan memberikan informasi kepada investor mengenai kinerja reksa dana.

Dalam penelitian ini didapat pemeringkatan kinerja reksa dana saham dengan metode sharpe, treynor dan jensen dengan hasil yang serupa. Hasil yang didapat terdapat 6(enam) reksa dana yang memiliki nilai kinerja yang lebih tinggi dari nilai kinerja IHSG. Jenis reksa dana saham tersebut ialah :

Asanusa Enhanced Strategy Fund

Batavia Dana Saham Optimal

Manulife Dana Saham

Manulife Saham Andalan

TRIM Kapital Plus

\section{KESIMPULAN DAN SARAN}

\section{Kesimpulan}

Dari penelitian yang dilakukan penulis terhadap 20 jenis reksa dana saham dengan periode januari 2014 sampai desember 2015, maka kesimpulan yang dapat diambil sebagai berikut:

Berdasarkan pengukuran kinerja menggunakan metode sharpe, treynor dan jensen didapat 6(enam) reksa dana saham yang memiliki kinerja yang sangat baik daripada kinerja IHSG. Reksa dana tersebut ialah Dari ketiga metode pengukuran kinerja reksa dana, maka reksa dana yang memiliki kinerja terbaik selama periode januari 2014 sampai desember 2015, Hasil kinerja reksa dana menggunakan metode sharpe, treynor, dan jensen memiliki hasil yang serupa, yang menunjukkan bahwa portofolio reksa dana saham terdiversifikasi dengan baik. Yaitu reksa dana:

Asanusa Enhanced Strategy Fund

Batavia Dana Saham Optimal

Manulife Dana Saham

Manulife Saham Andalan

TRIM Kapital Plus. 


\section{Saran}

Penelitian pengukuran kinerja reksa dana dengan 20 jenis reksa dana saham selama periode januari 2014 sampai desember 2015 telah dilakukan, maka saran - saran yang dapat diberikan sebagai berikut:

Bagi investor, dalam melakukan investasi sebaiknya investor melakukan penelitian terlebih dahulu mengenai kinerja reksa dana yang akan dipilih, sebaiknya dalam memilih investasi reksa dana saham tidak hanya berdasarkan pada nilai NAB/Unit, tetapi melalui perhitungan yang saksama dengan menggunakan metode-metode yang ada. Sehingga dapat m,emperoleh penilaian yang lebih baik dan tepat dalam memilih mengukur kinerja reksa dana. Investor yang hendaknya berinvestasi pada instrumen reksa dana saham, dapat menggunakan pengukuran kinerja reksa dana dari periode sebelumnya untuk sebagai bahan pertimbangan dalam berinvestasi, tetapi juga perlu diketahui bahwa kinerja reksa dana akan selalu berubah - ubah dan belum tentu hasil masa seksarang akan terulang untuk masa yang akan datang.

\section{DAFTAR PUSTAKA}

Pratomo E, P., \& Nugraha, U. (2009). Reksa Dana: Solusi Perencanaan Investasi di Era Modern. jakarta: Gramedia Pustaka Utama.

Tandelilin, E. 2010. Portofolio dan Investasi Teori dan Aplikasi. Edisi Pertama. Kanisius. Yogyakarta

http://www.ksei.co.id/services/registered-securities/mutuals

http://www.idx.co.id/id-id/beranda/publikasi/statistik.aspx

https://indopremier.com 


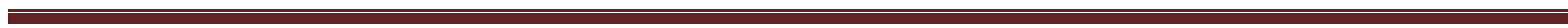
$\cdot$ 